\title{
KONSTRUKSI LEMBAGA JAMINAN UNTUK SAHAM SEBAGAI BENTUK DUKUNGAN PERKEMBANGAN BISNIS
}

\author{
Fani Martiawan Kumara Putra \\ Faculty of Law, Wijaya Kusuma Surabaya University \\ e-mail: fanimartiawan@gmail.com
}

\begin{abstract}
ABSTRAK
Utang-piutang sebagai kegiatan bisnis, sudah barang tentu bingkainya adalah perjanjian, kemudian pengamannya adalah agunan atau jaminan. Pada prinsipnya tidak ada utang tanpa adanya jaminan, karena walaupun tanpa adanya jaminan yang disepakati oleh para pihak, tetap akan ada jaminan yang diberikan oleh undang-undang sebagaimana Pasal 1131 Burgerlijk Wetboek. Pengaturan mengenai penjaminan juga semestinya berkembang mengikuti tuntutan perkembangan bisnis, namun selama belum ada pengaturan yang baru, dan masih perlunya identifikasi permasalahan yang lebih komprehensif, maka jalan keluarnya sudah barang tentu menggunakan penafsiran. Semakin berkembang pola bisnisnya, berkembang pula karakteristik utang-piutangnya, maka wajar manakala benda yang menjadi obyek jaminan juga berkembang. Sebagaimana saat ini, saham dapat dijadikan obyek jaminan. Sebagaimana aturan yang mendasarinya, saham dapat dijadikan obyek jaminan Gadai atau Fdusia. Undang-Undang memberikan 2 (dua) pilihan lembaga jaminan untuk obyek saham, oleh karenanya dalam penelitian ini akan dicari konstruksi lembaga jaminan untuk saham sebagai rumusan permasalahannya. Penelitian ini merupakan penelitian normatif. Hasil yang didapatkan dari penelitian ini adalah saham dengan segala aspeknya, akan lebih dapat mendukung kegiatan bisnis dan juga dapat diterapkan prinsip-prinsip penting Hukum Jaminan bagi debitornya manakala dijaminkan dengan lembaga jaminan Fidusia.
\end{abstract}

Kata Kunci: Saham; Hukum Jaminan; Jaminan; Gadai; Fidusia

\section{ABSTRACT}

The frame of a debt as a business activity is an agreement, then the security is collateral. In principle, there is no debt without collateral, because even if there is no collateral agreed upon by the parties, there will still be security object provided by law as Article 1131 Burgerlijk Wetboek. Arrangements regarding security law should also develop following the demands of business development, but as long as there are no new arrangements, and there is still a need to identify more comprehensive problems, the solution is certainly to use interpretation. As the pattern of business develops, the characteristics of debt are also developed, so that naturally the collateral object will also develop. As of now, stocks can be used as collateral objects. As with the underlying rules, stocks can be used as collateral for Gadai or Fiducia. The Law provides 2 (two) choices of collateral institutions for stock objects, therefore this study will look for the construction of security institutions as a formulation of the problem. This research is normative research. The results obtained from this study are stocks with all aspects, will be more able to support business activities and also can be applied important principles of security law for debtors when secured with Fiducia security institutions.

Keywords: Stocks; Security Law; Collateral; Gadai; Fiducia 


\section{PENDAHULUAN}

Sebagai negara yang berkembang, Indonesia saat ini mengalami kemajuan yang dapat dikatakan cukup pesat, kendati kemajuan tersebut disinggahi pula dengan krisis perekonomian yang juga tidaklah singkat, namun segenap pelaku usaha tetap melakukan upaya demi upaya guna mempertahankan eksistensi usahanya, hal ini dapat terlihat dari tetap berkembangnya aspek perekonomian pada berbagai sektor.

Manusia adalah penentu gerak dan suksesnya perekonomian tersebut. Hal ini mengingat manusia adalah makhluk yang pada hakekatnya mempunyai sifat Zoon Politicon dan Homo Economicus, di mana dapat diartikan bahwa manusia merupakan makhluk sosial yang tidak dapat hidup sendiri, dan mayoritas kegiatan yang dilakukan adalah dengan pertimbangan untung dan rugi, yang dapat kita sebut itu secara sederhana sebagai kegiatan bisnis.

Kegiatan bisnis yang merupakan mayoritas kegiatan manusia, harus ada penopangnya agar kegiatan bisnis tersebut dapat berjalan sebagaimana yang diharapkan. Penopang dalam hal ini adalah suatu pranata hukum. Demikian instrument yang akan menjadi tolak ukur utama adalah Konstitusi (Undang-Undang Dasar RI 1945) dan UndangUndang. Kendati demikian, perlu diingat bahwa kegiatan bisnis ini adalah suatu wujud interaksi para pihak, yang artinya sebenar-benar penopang utamanya adalah perjanjian yang dibuat oleh para pihak tersebut.

Hal ini mengingat amanah dalam Burgerlijk Wetboek (selanjutnya disebut BW), yaitu Pasal 1338 BW, yang menegaskan bahwa perjanjian yang dibuat oleh para pihak itu berlaku sebagai undangundang bagi para pembuatnya. Perlu dipahami bahwa kekuatan mengikat tersebut tidak serta merta mengikat para pihaknya, namun sudah barang tentu perjanjian tersebut lolos dalam uji keabsahan dengan menggunakan Pasal 1320 BW.

Perjanjian ini merupakan media yang membawa aturan hukum perikatan menjadi dapat di implementasikan pada para pihaknya. Sebagaimana diamanahkan oleh Pasal 1233 BW, bahwa salah satu sumber perikatan selain undang-undang adalah perjanjian. Keistimewaan saat hukum perikatan dapat diaplikasikan pada para pihak dalam perjanjian itu adalah isi dari perjanjian tersebut dapat dimintakan bantuan hukum untuk pemenuhannya. Kendati demikian perlu dipahami bahwa tidak semua perjanjian akan melahirkan perikatan, melainkan hanya perjanjian obligatoir saja, yaitu perjanjian yang para pihaknya sama-sama dibebani kewajiban, dan/atau diatur dalam Buku III BW.

Salah satu perjanjian yang mendominasi berdasarkan jumlah terjadinya di masyarakat, adalah perjanjian utang-piutang, yang lebih kita kenal dengan perjanjian kredit. Perjanjian ini sering terjadi di masyarakat baik itu dalam bentuk sebatas lisan, ataupun yang dituangkan dalam suatu perjanjian tertulis yang ditandatangani, bahkan tidak sedikit pula yang memanfaatkan karakter istimewa akta Notaris untuk perjanjian kreditnya.

Perjanjian kredit lebih sering dibuat, mengingat kredit ini merupakan suatu cara untuk memenuhi kebutuhan dana yang tidak sedikit dalam pengembangan suatu usaha. Pengembangan suatu usaha merupakan suatu tuntutan saat ini atas dasar globalisasi yang membawa pengaruh pada aspek perekonomian, hanya dengan terus mengembangkan usahanya, suatu kegiatan usaha akan tetap eksis, akan tetapi memang pengembangan suatu usaha akan sangat susah dan berpotensi terhambat manakala tanpa didampingi dengan dana yang cukup.

Kegiatan perkreditan ini tidak mungkin dilakukan dengan tanpa adanya agunan atau jaminan yang juga pula disertakan atau diminta oleh pihak yang memberi utang (berpiutang), hal ini sudah merupakan suatu hal yang umum, karena fungsi utama jaminan tersebut adalah memastikan terbayarnya piutang pihak yang memberikan utangnya.

Jaminan yang diharapkan tentu saja jaminan yang mempunyai nilai tinggi dan dapat diperjualbelikan, dalam hal ini adalah suatu benda. Namun memang diperbolehkan dalam sebagaimana Pasal 1820 BW, bahwa jaminan itu berupa seseorang yang menyanggupi dirinya sebagai penanggung utang.

Beragam benda telah digunakan masyarakat sebagai objek jaminan, baik itu televisi, kendaraan bermotor, perhiasan, rumah, tanah, hasil panen, ataupun kapal laut. Benda-benda tersebut manakala dijaminkan, tidak menggunakan lembaga jaminan yang sama, namun berbeda, mengingat di Indonesia ini terdapat 4 (empat) lembaga jaminan, yaitu Gadai, Hipotek, Hak Tanggungan, dan Fidusia. 
Gadai merupakan satu-satunya lembaga jaminan yang pengaturannya tidak mendapatkan pembaharuan sejak tahun 1848 hingga kini, yaitu masih diatur dalam Pasal1150-1160 BW. Salah satu benda yang dapat dijadikan objek Gadai, adalah salah satu bentuk surat berharga yang lebih dikenal dengan nama saham.

Undang-Undang Nomor 40 Tahun 2007 Tentang Perseroan Terbatas (selanjutnya disebut UUPT) redaksi Pasal 1 angka (1)nya menegasakan bahwa saham merupakan suatu bukti kepemilikan perseroan terbatas baik seluruhnya atau sebagian oleh seseorang, dimana seseorang yang memiliki saham dari suatu perseroan terbatas telah menyetorkan dananya untuk perseroan terbatas tersebut. Pengaturan selanjutnya mengenai kedudukan saham dalam suatu perseroan, terdapat dalam Pasal 48-62 UUPT.

Pasal 60 ayat (1) UUPT ini menegaskan bahwa saham merupakan benda bergerak. Oleh karena itu aturan dalam BW tidaklah aneh manakala penjaminan saham itu diamanahkan untuk menggunakan lembaga jaminan Gadai yang memang diperuntukkan untuk benda bergerak. Kendati demikian, dalam perkembangannya, tidak hanya Gadai yang dapat dipergunakan sebagai lembaga jaminan untuk saham Sebagaimana Pasal 60 ayat (2) UUPT, ditegaskan bahwa saham dapat dijadikan objek jaminan Gadai atau Fidusia.

Kata atau dalam pasal tersebut menimbulkan suatu penafsiran tersendiri, bahwa masyarakat dapat memilih, akan dijadikan objek jaminan Gadai atau Fidusia dengan segala konsekuensi yang ada pada lembaga jaminan tersebut. Demikian menurut penulis, hal ini adalah suatu ketentuan yang cuma-cuma saja, mengingat saham bukanlah seperti objek lain yang mana pemiliknya itu menjadi penentunya, apakah mau dijadikan objek Gadai atau Fidusia, karena perbedaannya adalah dalam hal penguasaannya. Saham lebih kepada suatu benda modal, yang akan digunakan untuk menopang eksistensi suatu Perseroan Terbatas atau semacamnya, oleh karenanya manakala dijadikan objek jaminan Gadai, ini akan menjadi suatu perbuatan hukum yang tidak mendukung kegiatan bisnis.

Tidak hanya karakter penguasaan objeknya, namun juga pemenuhan prinsip hukum jaminannya. Mana lembaga jaminan yang pada praktik yang didukung teorinya itu mampu mengaplikasikan seluruh prinsip hukum jaminan dengan baik saat saham menjadi objeknya. Ini yang tentunya nanti diharapkan dapat untuk ditentukan menjadi satu lembaga jaminan saja untuk saham.

\section{PERUMUSAN MASALAH}

Konstruksi lembaga jaminan untuk saham sebagai bentuk dukungan perkembangan bisnis.

\section{PEMBAHASAN}

Sebagaimana telah dijabarkan di atas, bahwa perjanjian utang-piutang merupakan salah satu bentuk perjanjian, yang mana merupakan penopang hubungan hukum para pihak dalam bidang hukum keperdataan. Pada utang-piutang, terdapat 2 (dua) pihak minimal, yaitu pihak yang berhak atas suatu prestasi (kreditor), dan pihak yang wajib untuk memberikan prestasi (debitor).

Perjanjian utang-piutang yang mana merupakan suatu perjanjian yang mana kedua belah pihaknya sama-sama dibebani kewajiban. Baik itu kreditor yang dalam perjanjian itu mempunyai kewajiban untuk memberikan piutang, dan debitor yang berkewajiban untuk membayar lunas utangnya. Artinya perjanjian utang-piutang ini merupakan perjanjian obligatoir, yang mana menimbulkan perikatan, asalkan perjanjian itu sah.

Manakala suatu perjanjian utang-piutang itu melahirkan perikatan sebagaimana di atas, maka saat objek perikatan (prestasi) itu tidak dipenuhi, kreditor kemudian memiliki 4 (empat) pilihan, yaitu: 1. Pemenuhan Perikatan; 2. Pembatalan Perikatan; 3. Pemenuhan Perikatan dengan Ganti Rugi; 4. Pembatalan Perikatan dengan Ganti Rugi.

Pada utang-piutang, kerapkali manakala pihak debitor sudah wanprestasi, yang dipilih oleh kreditor adalah pemenuhan perikatan dengan ganti rugi. Inilah pada hakekatnya mengapa dalam utang-piutang ini ada urgensi disertakan jaminan, agar supaya proses pemenuhan perikatan dengan ganti rugi ini dapat berjalan dengan lebih mudah dan lancar.

Jaminan digunakan sebagai pengaman, dalam arti pemberi kepastian kepada kreditor saat memberikan persetujuan pemberian utang kepada debitornya. Karena pada kenyataannya, semua utang baik itu dengan menggunakan jaminan yang diikat secara sah, ataupun utang yang menggunakan jaminan namun tidak diikat secara sah, terlebih lagi utang 
yang tidak diikat lebih lanjut dengan jaminan, itu sangat berpotensi mengalami keterlambatan atau kendala dalam pembayarannya. Melalui pengikatan jaminan, utang dapat dilunasi dengan cara menjual objek yang diikat sebaga jaminan. Kendati demikian, ada batasan yang merupakan prinsip di mana itu tidak dapat dilanggar, yaitu pengikatan jaminan itu haruslah dilakukan dengan sah. Oleh karenanya dalam penelitian ini, pengikatan jaminan yang dimaksud adalah yang dilakukan secara sah.

Kendati penjualan yang dimaksud itu nampak sangat menjanjikan, namun dalam praktiknya tidaklah selalu demikian lancarnya, penjualan objek jaminan yang dikenal dengan istilah eksekusi objek jaminan ini kerapkali menemui kendala, salah satu kendala yang sangat sering terjadi adalah dalam tahapan sita eksekusi, pada tahapan ini sering terjadi perlawanan dari pihak debitor dalam bentuk tidak mau menyerahkan objek jaminan yang sedang dikuasai olehnya. Meski begitu, perlawanan ini tetap dapat diselesaikan melalui bantuan Pengadilan yang nantinya dapat mengamanahkan pihak berwajib untuk melakukan sita atas objek tersebut. Hal ini diperbolehkan karena Hukum Jaminan memberikan keistimewaan pada kreditornya melalui prinsip Droit de Suite, prinsip di mana hak jaminan kebendaan yang melekat pada objek yang dijaminkan itu akan terus mengikuti kemanapun, kapanpun dan dimanapun objek yang dijaminkan itu berada selama masa utang-piutang dengan jaminan itu berlangsung.

Mengingat prinsip Droit de Suite yang begitu memudahkan proses eksekusi objek jaminan, maka dari itu dalam proses pengikatan objek jaminan diwajibkan yang mengikatkan itu adalah orang yang berhak, keadaan mana yang diakibatkan oleh prinsip Nemo Plus Iuris, yaitu orang tidak dapat mengalihkan hak melebihi hak yang ada padanya. Kepemilikan atas objek tersebut juga sudah barang tentu harus dapat dibuktikan secara hukum.

Droit de Suite menjadi suatu penanda bahwa suatu lembaga jaminan itu merupakan lembaga jaminan kebendaan yang melahirkan hak jaminan kebendaan dengan sah. Sebagai salah satu contonya, terdapat suatu lembaga jaminan yang dikenal dengan nama resi gudang di Indonesia, namun lembaga jaminan tersebut tidak menganut prinsip Droit de Suite, oleh karenanya lembaga jaminan tersebut tidak melahirkan hak jaminan kebendaan kepada si berpiutang.

Gadai sebagai lembaga jaminan yang dikenalkan pertama kali dalam BW, yang mana awal mula pengaturannya ada dalam Pasal 1150 BW dan berakhir pada Pasal 1160 BW, itu juga menganut prinsip Droit de Suite hanya saja tidak dengan tegas dinyatakan dalam suatu Pasal, melainkan prinsipnya dapat ditegakkan melalui penerapan asas inbezitstelling yang merupakan ciri khas lembaga jaminan Gadai sebagaimana ditegaskan dalam Pasal $1152 \mathrm{BW}$.

Inbezitstelling merupakan suatu prinsip dimana menegaskan bahwa objek jaminan yang akan dijaminkan itu harus dilepaskan dari kuasa nya debitor, untuk dikuasai oleh kreditor atau pihak ketiga. Ketentuan "pihak ketiga" disini pada hakekatnya karena pembuat undang-undang mencoba mengantisipasi bahwa belum tentu semua kreditor dapat menguasai, dalam artian menyimpan benda yang digadaikan oleh debitor. Adakalanya kreditor tidak mempunyai tempat penyimpanan barang elektronik yang memadai, gudang yang memadai, yang dapat digunakan untuk menyimpan barang gadai dalam waktu yang lama, tanpa adanya kerusakan seperti berjamur, dan lain sebagainya. Manakala demikian terjadi, maka diperbolehkan bagi kreditor untuk mencari pihak ketiga yang mempunyai fasilitas demikian, guna menyimpan barang yang digadaikan. Keadaan sebagaimana di atas ini, disyaratkan harus berdasarkan kesepakatan antara kreditor, debitor dan pihak ketiga, karena walau sedang dikuasai pihak ketiga, namun kreditor tetap wajib berkoordinasi dengan pihak ketiga yang menyimpan barang gadai tersebut diwajibkan untuk menjaga, termasuk merawat barang Gadai selama digadaikan, semata-mata agar tidak turun harganya. yang mana biaya perawatan tersebut ditanggung oleh debitor sebagaimana Pasal 1157 BW.

Pengaturan dalam hukum Romawi, khususnya di bidang hukum perjanjian, pada tingkat awal perkembangannya tidak terdapat bentuk yuridis yang memadai untuk memberikan jaminan baik benda bergerak dan tidak bergerak, karena hak Gadai dan hak Hipotek sebagai jaminan belum berkembang. Sementara itu, kebutuhan masyarakat Romawi akan bentuk lembaga jaminan pada saat itu sangat 
dirasakan dalam hubungannya dengan peminjaman uang.

Sebelum dikenal lembaga jaminan Gadai dan Hipotek, dalam praktik peminjaman uang, penjaminannya dilakukan dengan cara memberi jaminan kebendaan oleh debitor kepada kreditornya dengan pengalihan hak milik secara kepercayaan. Selain model penjaminan ini, juga dikenal bentuk penjaminan sesuai hukum Romawi, yaitu Pignus Depositum.

Kata "Pignus Depositum" terdiri dari dua kata, yaitu Pignus artinya gadai, dan Depositum artinya penitipan. Pignus dapat juga diartikan sebagai barang-barang yang disita oleh kreditor untuk pelunasan utang, sedangkan depositum diartikan sebagai kontrak mengenai penjaminan. Sehingga dapat diartikan melalui lembaga Pignus Depositum ini barang jaminan tidak menjadi milik kreditor, melainkan hanya menjadi pegangan dari kreditor. ${ }^{1}$

Pada akhir abad ke-19, terjadi perubahan dalam masyarakat yang ditandai dengan adanya krisis di bidang pertanian akibat datangnya serangan hama, sehingga para petani tidak mendapatkan hasil panennya. Konsekuensinya para pengusaha di bidang pertanian mengalami kekurangan modal. Para pengusaha tersebut tidak mungkin lagi melakukan investasi. Salah satu harapan untuk mendapatkan bantuan modal adalah dari Bank. Namun, Bank pada waktu itu tidak mau memberi kredit kepada para pengusaha pertanian kecuali disediakan barang jaminan berupa alat-alat pertanian dalam bentuk jaminan Gadai. Memanfaatkan fasilitas Hipotek juga terhalang karena Bank meminta jaminan tambahan selain jaminan Hipotek. Apabila para pengusaha pertanian memberi dua barang jaminan sekaligus (alat-alat pertanian dengan Gadai dan tanah pertanian dengan Hipotek), sudah tentu para pengusaha pertanian itu berhenti melanjutkan usahanya. Dalam hal praktik penggunaan lembaga jaminan dalam BW menemui kendala, akhirnya diatur lembaga jaminan baru yaitu Oogstverband. ${ }^{2}$

Lembaga jaminan Oogstverband ini diatur dalam Besluit Gubernur Jenderal Koninlijk Besluit Tanggal 24 Januari 1886, yang diundangkan melalui Staatsblad Nomor. 57 Tahun 1886. Pasal

1 Tan Kamelo. (2014). Hukum Jaminan Fidusia, Suatu Kebutuhan Yang Didambakan. Bandung: Alumni, h. 47.

2 ibid., h. 48.
1 Koninlijk Besluit tersebut menegaskan bahwa Oogstverband adalah suatu hak kebendaan atas hasil-hasil pertanian yang belum dipetik, atau sudah beserta perusahaan serta peralatan yang digunakan untuk pengolahan hasil pertanian itu, untuk jaminan agar supaya dipenuhi perjanjian untuk menyerahkan produk-produk itu kepada pemberi uang untuk dijual dalam komisi, dengan tujuan membayar uanguang persekot, bunga-bunga, ongkos-ongkos, dan uang provisi dari hasil penjualan. Pada prinsipnya Oogstverband adalah serupa dengan Gadai, hanya saja tanpa adanya pelepasan kekuasaan atas objek jaminan. Oogstverband saat itu merupakan lembaga jaminan kebendaan yang diakui dalam hukum positif Indonesia, dan mirip dengan "anti chresis" (suatu ikatan panen) yang diatur dalam Code Civil of the Philipines. $^{3}$

Oogstverband ini merupakan cikal bakal lahirnya jaminan Fidusia. Hubungan-hubungan Fidusia didasarkan pada kepercayaan dan terlalu memberi kewenangan kepada kreditor yang menjadi pemilik barang yang diarahkan sebagai jaminan. Dalam kepercayaan itu, kreditor tidak akan menyalahgunakan hak nya tanpa ada ketentuan dalam Undang-Undang atau Peradilan yang menetapkan kepercayaannya itu. Hubungan tersebut dapat menimbulkan keteganganketegangan hak dan kewajiban antara pemberi kredit dan pengambil kredit yang dibutuhkan dalam lalulintas kredit. Maka dari itu dalam hukum Romawi pada akhir jaman klasik, hilanglah Fidusia seiring berkembangnya hak-hak Gadai dan Hipotek sebagai hak jaminan kebendaan.

Oogstverband lahir kembali dengan nama dan pengaturan baru, yaitu Fidusia, untuk menjawab kebutuhan perkembangan jaman akibat berlakunya asas inbezitstelling pada Gadai yang merupakan satusatunya lembaga jaminan untuk benda bergerak.

Inbezitstelling menjadi pembeda utama antara Gadai dengan Fidusia, yang mana kedua lembaga jaminan ini merupakan lembaga jaminan yang tersedia di Indonesia bagi benda bergerak. Sebagaimana telah dijabarkan sebelumnya, Fidusia merupakan bentuk fasilitas dari pemerintah terkait perkembangan kebutuhan lembaga jaminan yang sesuai dengan karakter perkreditan di Indonesia. Fidusia merupakan lembaga jaminan untuk benda

${ }^{3}$ Subekti. (1986). Jaminan Untuk Pemberian Kredit Menurut Hukum Indonesia. Bandung: Alumni, h. 79. 
bergerak, yang mana bendanya tidak perlu dilepas dari kuasanya debitor sebagaimana Gadai, namun tetap bisa dikuasai oleh debitor untuk digunakan dalam mencari nafkah sehari-hari. Atas dasar hal ini, maka penulis lebih suka menyebut Gadai itu digunakan manakala objek yang akan dijaminkan itu adalah benda bergerak biasa, sedangkan Fidusia itu digunakan manakala objek yang dijaminkan akan dijaminkan itu adalah benda bergerak modal.

Pasal 1 angka (1) dan (5) UUJF menegaskan bahwa Fidusia adalah pengalihan hak kepemilikan suatu benda atas dasar kepercayaan dengan ketentuan bahwa benda yang hak kepemilikannya dialihkan tersebut tetap dalam penguasaan pemilik benda, dan Pemberi Fidusia adalah orang perseorangan atau korporasi pemilik benda yang menjadi objek Jaminan Fidusia. Redaksi Pasal tersebut menegaskan bahwa dalam membebani suatu objek dengan jaminan Fidusia, haruslah benar-benar dapat dibuktikan bahwa pemberi Fidusia (debitor) adalah orang yang berwenang menguasai (beschikkingbevoegdheid) terhadap benda tersebut, karena nantinya akan terjadi perpindahan hak kepemilikan secara kepercayaan atas benda tersebut.

Jika seorang debitor menyerahkan harta benda sebagai jaminan kepada kreditornya berarti sebagian kekuasaan atas kepemilikan benda itu telah beralih kepada kreditor. Penyerahan hak kepemilikan atas objek Fidusia tersebut mencakup hak milik atas benda dan hak penguasaan atas suatu benda. Penyerahan hak milik ini berarti objek Fidusia miliknya diserahkan dari pemberi Fidusia (debitor) kepada penerima Fidusia (kreditor), namun jika yang diserahkan adalah penguasaan atas suatu benda, berarti objek Fidusia diserahkan secara kekuasaan, sehingga bukan hak milik. ${ }^{4}$

Melalui pendapat tersebut dapat dipahami bahwa penyerahan hak milik dalam Fidusia bukanlah dalam maksud perpindahan hak milik yang sepenuhnya, karena hanya sebagian kekuasaan atas kepemilikan itulah yang dilepaskan oleh debitor dan diberikan kepada kreditor, sedangkan sebagian kekuasaan lainnya masih dikuasai debitor. Ketentuan ini semata-mata hanya untuk melindungi kreditor dalam mendapatkan pelunasan piutangnya. Lagipula, UUJF sendiri melarang kreditor memiliki objek jaminan Fidusia manakala debitor tidak sanggup

\footnotetext{
${ }^{4}$ Tan Kamelo, op.cit., h. 106.
}

membayar utangnya sebagaimana Pasal 33 UUJF. Artinya manakala peralihan hak kepemilikan dalam Pasal 1 UUJF itu dimaksudkan peralihan hak milik sepenuhnya, maka seharusnya tidak ada aturan semacam Pasal 33 di UUJF.

Kendati perbedaan mendasarnya adalah asas Inbezitstelling, namun perbedaan lain yang juga cukup menonjol adalah pengaturannya. Gadai diatur hanya dalam 10 (sepuluh) pasal, sedangkan Fidusia terdapat 41 (empat puluh satu) pasal untuk pengaturannya. Melalui hal ini dapat dipahami bahwa meskipun Gadai tidak banyak menemui kendala dalam praktiknya, belum tentu demikian juga untuk Fidusia, oleh karenanya Fidusia diatur lebih rinci. Walaupun telah diatur secara komprehensif, pada kenyataannya tidak berhenti permasalahan mengenai utang-piutang dengan objek jaminan Fidusia.

Mendasar pada perbedaan inti dan singkat sejarah perkembangan dua lembaga jaminan (Gadai dan Fidusia) yang telah dijabarkan di atas, maka setidaknya saat ini telah dapat diketahui keuntungan dan kerugian saat menjaminkan saham dengan lembaga jaminan tersebut. Perihal mencari lembaga jaminan dengan konstruksi yang mendukung untuk saham sebagai objeknya, maka juga harus dilihat praktiknya selama ini.

Perlu diingat bahwa lembaga jaminan yang ideal adalah: 1. Dapat secara mudah membantu perolehan kredit oleh pihak yang memerlukan kredit; 2 . Tidak melemahkan potensi (kekuatan) si pencari kredit untuk melakukan atau meneruskan usahanya; 3 . Memberikan kepastian kepada si pemberi kredit, bahwa barang jaminan setiap waktu tersedia untuk di eksekusi dan mudah diuangkan untuk melunasi utangnya si penerima kredit. ${ }^{5}$

Pengaturan mengenai saham dalam UUPT terdapat dalam Pasal 48-62 UUPT. Saham juga dapat didefinisikan sebagai tanda penyertaan modal seseorang atau pihak (badan usaha) dalam suatu perusahaan atau perseroan terbatas. Dengan menyertakan modal tersebut, maka pihak tersebut memiliki klaim atas pendapatan perusahaan, klaim atas aset perusahaan, dan berhak hadir dalam Rapat Umum Pemegang Saham (RUPS). ${ }^{6}$

\footnotetext{
${ }^{5}$ Subekti, op.cit., h. 84 .

${ }^{6}$ Gatot Supramono. (2014). Transaksi Bisnis Saham dan Penyelesaian Sengketa Melalui Pengadilan. Jakarta: Kencana Prenada Media Group, h. 5.
} 
Jenis saham berdasarkan cara peralihan terbagi menjadi dua, yakni Saham atas unjuk (Bearer Stock) dan Saham atas nama (Registered Stock). Saham atas unjuk adalah saham yang tidak mempunyai nama pemilik saham tersebut. Sedangkan, Saham atas nama adalah saham yang ditulis dengan jelas siapa pemiliknya. Jenis saham berdasarkan hak tagihan juga terbagi menjadi dua, yakni Saham Biasa (Common Stock) dan Saham Preferen (Preferred Stock). Saham Biasa adalah saham yang menempatkan pemiliknya pada posisi paling akhir dalam hal pembagian deviden, hak atas harta kekayaan perusahaan apabila perusahaan tersebut mengalami likuidasi. ${ }^{7}$

UUPT mengenal klasifikasi saham, yang dimaksud dengan klasifikasi saham adalah kelompok saham yang satu sama lain mempunyai karakteristik yang sama, dan karakteristik tersebut membedakannya dengan saham yang merupakan kelompok saham dari klasifikasi yang berbeda. Dalam Pasal 53 ayat (2) UUPT ditentukan, setiap saham dalam klasifikasi yang sama memberikan kepada pemegangnya hak yang sama, misalnya hak suara, hak menerima dividen hak pengalihan suatu klasifikasi saham ke klasifikasi saham yang lain. ${ }^{8}$

Ketentuan mengenai karakteristik saham dalam UUPT diatur pada Pasal 53, di mana karakteristik saham tersebut adalah sebagai berikut:

1. Saham biasa; Berdasarkan penjelasan Pasal 53 ayat (3), yang dimaksud dengan Saham biasa adalah saham yang mempunyai hak suara untuk mengambil keputusan dalam RUPS mengenai segala hal yang berkaitan dengan pengurusan Perseroan, mempunyai hak untuk menerima dividen yang dibagikan, dan menerima sisa kekayaan hasil likuidasi.

2. Saham dengan hak suara atau tanpa hak suara;

3. Saham dengan hak khusus untuk mencalonkan anggota Direksi dan/atau anggota Dewan Komisaris;

4. Saham yang setelah jangka waktu tertentu ditarik kembali atau ditukar dengan klasifikasi saham lain;

${ }^{7}$ M. Irsan Nasarudin. (2014). Aspek Hukum Pasar Modal Indonesia. Jakarta: Kencana Prenada Media Group, h. 189-190.

${ }^{8}$ James Julianto Irawan. (2014). Surat Berharga Suatu Tinjauan Yuridis dan Praktis. Jakarta: Prenada Media Group, h. 256.
5. Saham yang memberikan hak kepada pemegangnya untuk menerima dividen lebih dahulu dari pemegang saham klasifikasi lain atas pembagian dividen secara komulatif atau nonkomulatif;

6. Saham yang memberikan hak kepada pemegangnya untuk menerima lebih dahulu dari pemegang saham klasifikasi lain atas pembagian sisa kekayaan Perseroan dalam likuidasi.

Syarat formal dari surat saham, yaitu: ${ }^{9} 1$. Tulisan "SAHAM" pada lembaran surat saham (Pasal 31 ayat (1) UUPT); 2. Nilai nominal, harus dalam mata uang Republik Indonesia (Pasal 49 ayat (1) UUPT); 3. Nama pemilik saham (Pasal 48 ayat (1) UUPT); 4. Tanggal diterbitkannya; 5. Nomor seri saham (Pasal 50 UUPT); 6. Penerbit dan tanda tangan penerbitannya (direktur dan komisaris); 7. Klasifikasi saham (Pasal 53 UUPT).

Agar tidak terjadi hal-hal yang tidak diinginkan (merugikan), maka saham wajib dicacat dalam Daftar Pemegang Saham, dan Daftar Khusus. ${ }^{10}$

Berkaitan dengan saham yang dijadikan sebagai objek jaminan, maka terdapat 2 (dua) teori penting, yaitu: ${ }^{11}$

1. Pengalihan manfaat dalam Gadai. Pemegang Gadai di samping menerima pengalihan fisik dari benda yang digadaikan tetapi juga berhak untuk memungut hasil atau mengambil manfaat dari benda objek Gadai tersebut. UUPT tidak mengatur hal ini, maka berdasarkan prinsip ini, pemegang Gadai berhak untuk menerima manfaat dari Gadai saham, termasuk menerima dividen dan sisa hasil pembagian dalam likuidasi Perseroan. Namun UUPT dengan jelas memberikan batas untuk hak suara tetap pada pemegang saham (UUPT Pasal 60 ayat (4));

2. Saham sebagai suatu unitas. Saham dari suatu Perseroan Terbatas merupakan suatu kesatuan yang utuh. Pasal 52 ayat (4) UUPT dengan tegas menyebutkan bahwa setiap saham memberikan hak kepada pemiliknya hak yang tidak dapat dibagi-bagi. Itulah sebabnya hak suara tetap berada pada pemegang saham (pemiliknya), bukan pada pihak penerima Gadai (Pasal 60 ayat (4) UUPT).

\footnotetext{
${ }^{9}$ ibid., h. 167.

${ }^{10}$ ibid., h. 176.

${ }^{11}$ ibid.
} 
Berkaitan dengan penjabaran singkat di atas, juga memperhatikan Pasal 60 UUPT, maka dapat dengan jelas diketahui bahwa saham merupakan benda bergerak.

Dasar hukum mengenai objek saham dalam lembaga jaminan Gadai sudah barang tentu tunduk pada Pasal 1153 BW, yang mana redaksinya adalah hak Gadainya si berpiutang akan lahir manakala ada pemberitahuan mengenai digadaikannya benda bergerak tak berwujudnya si berutang, kepada orang yang sebenarnya punya hak untuk "partisipasi" atau "penggunaan" barang yang digadaikan itu, dan orang yang punya hak tersebut bisa meminta bukti tertulis atas digadaikannya barang itu. ${ }^{12}$ Pasal ini merupakan suatu konsekuensi dari Pasal 1152 BW yaitu adanya asas inbezitstelling, oleh karena benda bergerak tidak berwujud yang digadaikan itu akan dilepas dari kuasanya debitor (si berutang), maka segala aspek pada benda tersebut (termasuk untuk apa dan kepada siapa pemanfaatannya) harus mengetahuinya, mengingat selama digadaikan halhal tersebut juga tidak akan bisa terwujud karena adanya asas inbezitstelling.

Pada penjaminan saham menggunakan Gadai, diketahui dari praktik penjaminan yang diteliti oleh penulis di suatu kantor Notaris, disampaikan bahwa karakter perjanjian utang-piutangnya dan perjanjian jaminannya adalah menjadi satu kesatuan, dengan kata lain Notaris tersebut hanya membuat satu perjanjian yaitu perjanjian utang-piutang, yang mana didalamnya juga ada klausula mengenai pemberian dan detail saham yang akan digunakan sebagai objek Gadai. Praktik ini sudah menjadi cara umum untuk penjaminan saham menggunakan lembaga jaminan Gadai.

Praktik sebagaimana di atas adalah suatu praktik penjaminan yang mengesampingkan prinsip asesoir pada lembaga jaminan yang telah dijabarkan di atas, yaitu prinsip dimana perjanjian pokok (utangpiutang) berbeda dengan perjanjian tambahan (penjaminan), karena sifatnya perjanjian tambahan itu lahir dari perjanjian pokok. Pada lembaga jaminan Gadai, praktik ini mengesampingkan Pasal 1151 BW. Pada Pasal tersebut ditegaskan mengenai

\footnotetext{
12 Kashadi. (2016). "Analisis Perjanjian utang-Piutang dengan Jaminan Gadai Saham Pada Kasus Deutsche Bank Aktiengesellschaft Melawan Beckett PTE. LTD. Diponegoro Law Journal. Volume 5 Nomor 3 Tahun 2016. Semarang: Universitas Diponegoro, h. 10.
}

perjanjian Gadai, yang mana ini adalah perjanjian asesoir yang dimaksud, yang bentuk implementasi praktiknya adalah dapat berupa surat bukti Gadai dengan bentuk yang disepakati para pihak, yang mana memuat identitas dan tanda tangan para pihak. Berbeda dengan penjaminan saham dengan lembaga jaminan Gadai sebagaimana penulis utarakan di atas, keseluruhan penjaminan Gadai dilaksanakan hanya dengan satu perjanjian saja, perjanjian Gadai ada di dalam perjanjian utang-piutang.

Pada praktik sebagaimana di atas itu juga, maka prinsip pada Pasal 1153 BW sebagaimana telah dijabarkan sebelumnya, yaitu mengenai cara tambahan publisitas khusus untuk benda bergerak tidak berwujud, itu menjadi kabur, dalam artian apakah dilaksanakan atau tidak, mengingat adanya keterkaitan dengan prinsip inbezitstelling yang ada dalam Pasal 1152 BW. Singkatnya manakala pemberitahuan akan adanya saham dijaminkan itu dilaksanakan, maka prinsip inbezitstelling baru dapat dilakukan. Karena dengan telah diberitahukan, barulah saham itu dapat dilakukan penguasaan oleh pihak kreditor atau pihak ketiga yang ditentukan dan disepakati, demikian artinya hak suara dan aspekaspek lain pada saham tersebut sudah tidak lagi dapat dinikmati oleh debitor.

Keadaan di atas ini sudah barang tentu cukup dirasa memberatkan bagi debitor, karena sejatinya saham sifatnya mampu memberi keuntungan pada debitor, oleh karenanya manakala dijaminkan itu alangkah baiknya debitor masih tetap dapat menikmati keuntungan dan fungsi dari saham tersebut, belum lagi aspek pengalihan saham yang nantinya sudah tentu akan berbenturan dengan Pasal 1152, 1153, 1159 BW, juga beban tugas kreditor menjaga nilai saham itu tidak merosot sebagaimana Pasal 1157 BW juga merupakan tugas yang tidak mudah. ${ }^{13}$

Berdasarkan penjabaran di atas, maka sudah saatnya memanfaatkan lembaga jaminan yang memberikan kebebasan pemanfaatan saham itu kepada yang berkompeten, juga agar nilainya tidak merosot, mempertimbangkan pula dua teori terkait penjaminan saham yang sudah disebutkan diatas.

${ }^{13}$ Kathleen C. Pontoh. (2016). "Jaminan Perlindungan Hukum Terhadap Kreditor Pemegang Gadai Saham Pada Bank Umum Nasional di Indonesia”. Jurnal Lex Crimen. Volume V Nomor 4 Tahun 2016. Manado: Universitas Sam Ratulangi, h. 156. 
Selain Gadai, lembaga jaminan yang tersedia adalah Fidusia. Hal inilah hakekatnya mengapa dalam UUPT disebutkan 2 (dua) lembaga jaminan yang tersedia untuk saham, pertama Gadai karena memang benda bergerak tidak berwujud dapat dijaminkan dengan Gadai, namun ada konsekuensinya sebagaimana dibahas di atas, kemudian juga dapat memanfaatkan Fidusia sebagai lembaga jaminan yang mana tidak ada konsekuensi sebagaimana menggunakan Gadai. Kendati demikian Fidusia juga bukan merupakan lembaga jaminan yang sempurna, oleh karenanya untuk penjaminan saham dengan menggunakan Fidusia, tetap ada konsekuensinya.

Melalui lembaga jaminan Fidusia, maka asas inbezitstelling tidak diberlakukan, sebagaimana pembeda utama jaminan Fidusia dengan Gadai, yaitu mengenai karakter penguasaan benda nya. Penguasaan dan pemanfaatan benda tetap ada pada debitor, hal ini sangat utama dan sangat cocok manakala objeknya adalah saham, aspek-aspek pada saham tersebut seperti hak suara dan lainnya bisa tetap dimanfaatkan oleh debitor.

Utang-piutang dengan jaminan Fidusia diperlukan akta Notaris sebagai bagian dari keseluruhan prosesnya. Dimulai dari perjanjian utang-piutang, lalu pembuatan akta jaminan Fidusia oleh Notaris, kemudian dilakukan pendaftaran, hal ini harus dipenuhi semua agar penjaminan Fidusia itu sah, sebagaimana Pasal 11 UUJF. Demikian artinya prinsip perjanjian jaminan saham sebagai perjanjian asesoir itu harus dan akan terpenuhi melalui lembaga jaminan Fidusia.

Manakala saham tersebut perlu untuk dialihkan karena suatu alasan tertentu, hal ini bukanlah suatu masalah, karena dalam Fidusia mengatur mengenai penjaminan barang persediaan, pengaturan yang memfasilitasi debitor yang menjaminkan barang yang diperdagangkan, dan saat salah satu barang itu dijual, maka debitor wajib mengganti barang yang sama atau yang nilainya sama, maka dari itu pada hakekatnya dititikberatkan pada nilai nominal keseluruhan barang persediaan tersebut. Hal ini sebagaimana Pasal 20-23 UUJF.

Demikian untuk saham yang dijadikan objek jaminan, kemudian karena suatu alasan tertentu saham tersbut menjadi penting untuk dipindahtangankan, maka dengan menggunakan jaminan Fidusia bisa diperjanjikan terlebih dahulu bahwa saham dengan nomor dan hak suara dan aspek terkait yang tercatat dalam akta jaminan Fidusia itu suatu saat dapat dialihkan, namun debitor wajib menggantinya dengan saham yang lain yang nilainya sama dengan saham yang dialihkan. Perjanjian semacam ini dapat dituangkan dalam Akta Jaminan Fidusia yang dibuat oleh Notaris. Agar kemudian tidak mengalami kerumitan dengan kewajiban pendaftaran ulang akta jaminan Fidusia saat ada pengalihan saham, maka juga perlu dibuat klausula-klausula khusus yang komprehensif (yang juga sebagaimana penjaminan barang persediaan) dalam akta jaminan Fidusia tersebut.

Berkaca pada pengaturan jaminan Fidusia untuk barang persediaan, maka tidak kalah pentingnya yaitu pengawasan yang harus dilakukan, baik itu dalam bentuk pemeriksaan berkala yang dilakukan langsung oleh kreditor atas keadaan saham yang sedang dijaminkan kepadanya, atau pemberitahuan berkala oleh debitor kepada kreditor, tentang keadaan saham yang saat ini sedang dijaminkan. Manakala hal-hal di atas ini terealisasi, maka kreditor tetap mempunyai kedudukan yang aman, walaupun saham tersebut masih dikuasai oleh debitor dan berpotensi untuk dipindahtangankan.

Jaminan Fidusia bukanlah lembaga jaminan yang sempurna, karena seringkali jaminan Fidusia tidak menjadi pilihan bagi para pelaku usaha, karena adanya satu pengaturan yang dianggap krusial, yaitu pengaturan pada Pasal 1 angka (1) UUJF, yang menegaskan bahwa Fidusia adalah pengalihan hak kepemilikan suatu benda atas dasar kepercayaan, dan benda yang hak kepemilikannya dialihkan tersebut tetap dalam penguasaan pemilik benda.

Ketentuan tersebut di atas, perpindahan hak milik itu harus diartikan bukanlah perpindahan hak milik dalam arti sepenuhnya dan sebenar-benarnya. Pembuat UUJF pun tidak menghendaki demikian, karena manakala diperhatikan ketentuan Pasal 33 UUJF ditegaskan bahwa segala janji yang memberikan kewenangan kepada kreditor untuk memiliki benda yang dibebani jaminan Fidusia manakala debitor cidera janji adalah batal. Artinya kalaupun Pasal 1 angka (1) UUJF itu diartikan ada perpindahan hak milik yang sepenuhnya dari debitor ke kreditor atas benda yang dijaminkan, namun tetap saja saat debitor cidera janji itu kreditor dilarang memiliki objek jaminan tersebut, kemudian disini jadi tidak nampak 
arti adanya peralihan hak milik sepenuhnya tersebut. Apakah hak milik itu berpindah selama debitor belum dapat dikatakan wanprestasi, lalu setelah debitor masuk dalam keadaan wanprestasi itu hak milik berpindah lagi ke debitor, ini juga tidak mungkin menjadi pertimbangan pembuat UUJF. Karena hal ini akan menimbulkan pengertian bahwa di debitor yang awalnya itu adalah pemilik, itu berubah menjadi peminjam pakai, penulis tidak sependapat dengan hal ini, apalagi manakala objeknya adalah benda persediaan atau saham sebagaimana dipaparkan di atas. Manakala tidak dapat diterapkan penafsiran ini pada objek benda persediaan, maka juga tidak sepatutnya diterapkan untuk yang objeknya selain benda persediaan, mengingat sama-sama diatur dan bersumber pada UUJF.

Penafsiran yang tepat menurut penulis atas Pasal 1 angka (1) UUJF itu adalah hak miliknya tidak berpindah sepenuhnya, namun hanya "dipercaya" berpindah kepada pihak kreditor, agar memberi kedudukan yang aman pada kreditor mengingat potensi susahnya dilakukan eksekusi karena objek yang dikuasai oleh debitor. Pola levering constitutum posessorium di Fidusia ini hanya dalam rangka jaminan pelunasan utang, dari awalnya tidak pernah ada tujuan perpindahan hak milik. Para pihak juga diberikan batasan-batasan dalam pengaturan UUJF, hal ini ditujukan semata-mata agar lembaga jaminan Fidusia tetap dapat berjalan tertib dan terus memfasilitasi para pelaku usaha.

\section{PENUTUP}

\section{Kesimpulan}

Saham manakala dijadikan objek jaminan, terdapat dua lembaga yang disediakan untuk medianya oleh UUPT, yaitu Gadai dan Fidusia. Mendasarkan pada penjabaran di atas, karakter praktik penerapan prinsip Hukum Jaminan pada Gadai dan Fidusia saat saham dijadikan objek jaminan sudah pasti Fidusia lebih unggul dan lebih mampu memberikan perlindungan hukum kepada kreditor dan memfasilitasi kebutuhan tuntutan bisnis pihak debitor.

\section{Rekomendasi}

Pemerintah perlu untuk menetapkan satu lembaga jaminan yang utama untuk saham, sehingga pelaku bisnis juga akan memahami bahwa ia sedang diarahkan oleh pemerintah untuk pemenuhan tuntutan bisnis yang akan memberinya perlindungan hukum lebih baik.

\section{DAFTAR PUSTAKA}

\section{Peraturan Perundang-undangan:}

Undang-Undang No 10 Tahun 1998 tentang Perubahan atas Undang-Undang Nomor 7 Tahun 1992 tentang Perbankan (Lembaran Negara Nomor 182, Tambahan Lembaran Negara Nomor 3790).

Undang-Undang No 42 Tahun 1999 tentang Jaminan Fidusia (Lembaran Negara Nomor 168, Tambahan Lembaran Negara Nomor 3889).

Undang-Undang No 40 Tahun 2007 tentang Perseroan Terbatas (Lembaran Negara Nomor 106, Tambahan Lembaran Negara Nomor 4756).

\section{Buku:}

James Julianto Irawan. (2014). Surat Berharga Suatu Tinjauan Yuridis dan Praktis. Jakarta: Prenada Media Group.

Tan Kamelo. (2014). Hukum Jaminan Fidusia, Suatu Kebutuhan Yang Didambakan. Bandung: Alumni.

M. Irsan Nasarudin. (2014). Aspek Hukum Pasar Modal Indonesia. Jakarta: Kencana Prenada Media Group.

Subekti. (1986). Jaminan Untuk Pemberian Kredit Menurut Hukum Indonesia. Bandung: Alumni.

Gatot Supramono. (2014). Transaksi Bisnis Saham dan Penyelesaian Sengketa Melalui Pengadilan. Jakarta: Kencana Prenada Media Group.

\section{Jurnal:}

Kashadi. (2016). "Analisis Perjanjian utang-Piutang dengan Jaminan Gadai Saham Pada Kasus Deutsche Bank Aktiengesellschaft Melawan Beckett PTE. LTD." Diponegoro Law Journal. Volume 5 Nomor 3 Tahun 2016. Semarang: Universitas Diponegoro.

Kathleen C. Pontoh. (2016). "Jaminan Perlindungan Hukum Terhadap Kreditor Pemegang Gadai Saham Pada Bank Umum Nasional di Indonesia." Jurnal Lex Crimen. Volume V Nomor 4 Tahun 2016. Manado: Universitas Sam Ratulangi. 